\title{
Spatial and temporal variation of benthic macroinvertebrate communities along an urban river in Greater Manchester, UK
}

\author{
Cecilia Medupin (D)
}

Received: 8 October 2018 / Accepted: 9 December 2019/Published online: 3 January 2020

(C) The Author(s) 2020

\begin{abstract}
Urban rivers face challenges of increased human activities which also affect river organisms. In order to enhance freshwater biodiversity in urban rivers, it is important to determine how the benthic macroinvertebrate communities are influenced by key abiotic factors. This was investigated in this paper through the study of the spatial and temporal variations of benthic macroinvertebrates and water quality variables at the urban River Medlock in Greater Manchester, UK. Samples were obtained from five sections of the catchment (S1 to S5) over a period of 14 months and the results were compared with the standard requirement of the European Union's Water Framework Directives. Multivariate tests including SIMPER (similarity percentages), PCA (principal component analysis) and BIOENV (biological and environmental) were carried out on the data in order to determine the environmental variables which most influenced the benthic macroinvertebrates. PCA of environmental variables indicated that $34 \%$ of the overall variance was heavily weighted on nutrients and catchment area (negatively on altitude and slope), $17 \%$ represented river substrate and the $12 \%$ represented discharge. The BIOENV analysis also indicated altitude, slope, catchment area, discharge and conductivity as the variables which influenced the biological communities. SIMPER analysis showed a difference between the upper and lower sections of the river with some sensitive
\end{abstract}

C. Medupin $(\bowtie)$

School of Earth and Environmental Sciences, The University of Manchester, Oxford Road, Manchester M13 9PL, UK

e-mail: cecilia.medupin@manchester.ac.uk taxa at the upper sites and showed that more organisms are present during spring. Apart from the lowest section of the river, the EU Water Framework Directive classification showed that other sites achieved the 'good ecological status'. While 32 taxa groups were identified, abundant Baetidae, Chironomidae and Oligochaeta were recorded at all sites and seasons. The scores for biotic indices Whalley Hawkes Paisley and Trigg (WHPT) and Biological Monitoring Working Party (BMWP) were found to be similar. By the application of surrogate variables such as percentage urban cover, catchment area and total number of organism, the influence of urbanisation could be seen in the abundance of organisms over time and space.

Keywords Benthic macroinvertebrates . Physicochemical · Biotic indices $\cdot$ Multivariate tests, water quality, urban area

\section{Introduction}

Rivers provide services that are beneficial to all living organisms including cultural, provisional, regulatory and supporting roles. Although these ecosystem services are provided naturally, urban rivers are threatened by morphological adjustment, channel modifications and altered river landscapes, all of which affect stream health, ecological structure and function (Meyer et al. 2005; Paul and Meyer 2001; Walsh et al. 2005, 2012). Bank undercutting in urban rivers can reduce the habitat available for biological communities such as benthic 
macroinvertebrates in streams (Chadwick et al. 2010; Voelz et al. 2005). These modifications increase erosion rates, result in sediment production especially for lands that have been cleared for building and increase runoff into rivers leading to larger and more frequent floods. In urban rivers, changes to peak discharge, lag time, flood frequency and total runoff have been reported to increase the flashiness of the flow regime (Chin 2006).

While urban impacts on surface waters do not only occur at local and national scales, global impacts of urban rivers have been reported by Chin (2006) given the challenge of increasing human population and development. With increasing urban development, there is a pressing need to evaluate water quality in view of maintaining, protecting and restoring river organisms and biodiversity (Booth et al. 2005; Morley and Karr 2002).

As water is a resource which needs to be protected, maintained and restored, one of the most effective ways to determine stream health is to assess the benthic macroinvertebrates as biological indicators. This is due to their ease of collection for rapid assessments and their sensitivity to a range of stress including sewage pollution (e.g. Hellawell 1986; Lock et al. 2011; Metzeling et al. 2003). Among other biological variables, benthic macroinvertebrates are the most commonly used all over the world. In order to quantify biological status in rivers, biotic indices are applied as numerical expressions combining quantitative measures of species diversity with qualitative information on the ecological sensitivity of individual species (Czerniawska-Kusza 2004).

Biotic indices reveal what may not be shown by physicochemical variables (Purcell et al. 2002). For example, the index Biological Monitoring Working Party (BMWP) score system was developed for UK waters (Hawkes 1997) as a biological quality indicator to assess the pollution status of rivers. The BMWP index ranks individual macroinvertebrate families from 1 to 10 in increasing order of putative sensitivity to organic pollution, and the score is the sum of all scores from invertebrate families recorded in the sample (Hawkes 1997). The greater their tolerance to pollution, the lower the BMWP score system and vice versa (Armitage et al. 1983). Thus, the BMWP score is calculated based on the number of families sampled but not by abundances within those families. In order to address this gap, the European Union developed an index through the Water Framework Directive ('WFD', Directive 2000/60/EC) called the Whalley, Hawkes, Paisley and Trigg
(Environment Agency 2015; WFD-UK Technical Advisory Group (UKTAG) 2014). The Whalley, Hawkes, Paisley and Trigg (WHPT) ASPT index (Environment Agency 2015) aims to integrate the abundance weighting limitation of the BMWP scoring system. The index identifies the effects of pressures on rivers with the ultimate aim to maintain or restore them to good ecological status as part of the WFD requirement. While the BMWP is based on the analysis of 82 taxa, the WHPT is based on 106 taxa so its sensitivity is slightly greater. The biological indicators of Biological Monitoring Working Party and the Whalley, Hawkes, Paisley and Trigg ASPT indices were applied to the results in order to assess the overall quality status while testing the differences in the outcomes. A river will achieve 'Good Ecological Status' classification for WFD when both physicochemical and biological variables are 'good'. The lowest classification on any of the analysed parts is used to determine the overall status of the surface waters ('WFD', Directive 2000/60/EC).

Elosegi et al. (2017) suggest using three methods of ecosystem management (similar to those used in medicine) - diagnosis, treatment and prevention to effectively diagnose river conditions. In this study, the diagnosis was determined through spatial and temporal assessment for benthic macroinvertebrates and physicochemical variables in order to identify where adjustment process has taken place in the river that could have affected the density and diversity of the organisms. These variations within the catchment can imply different strategies and may be required to handle spatially distributed response mechanisms (Chin and Gregory 2005). The aims of this study are also to describe, measure and analyse the patterns of benthic macroinvertebrate communities' assemblage in relation to study sites and environmental variables.

\section{Materials and methods}

\section{Study site}

The River Medlock forms part of the 1776 square miles Mersey catchment and is one of the most urbanised in the UK (Environment Agency 2009). With a catchment area of 22.2 square miles and the average yearly flow rate is $0.82 \mathrm{~m}^{3} \mathrm{~s}^{-1}$ (CEH 2017), the River Medlock (see Fig. 1) is 13.67 miles in length and rises in the Pennine hills to the Northeast of Oldham in Greater Manchester 


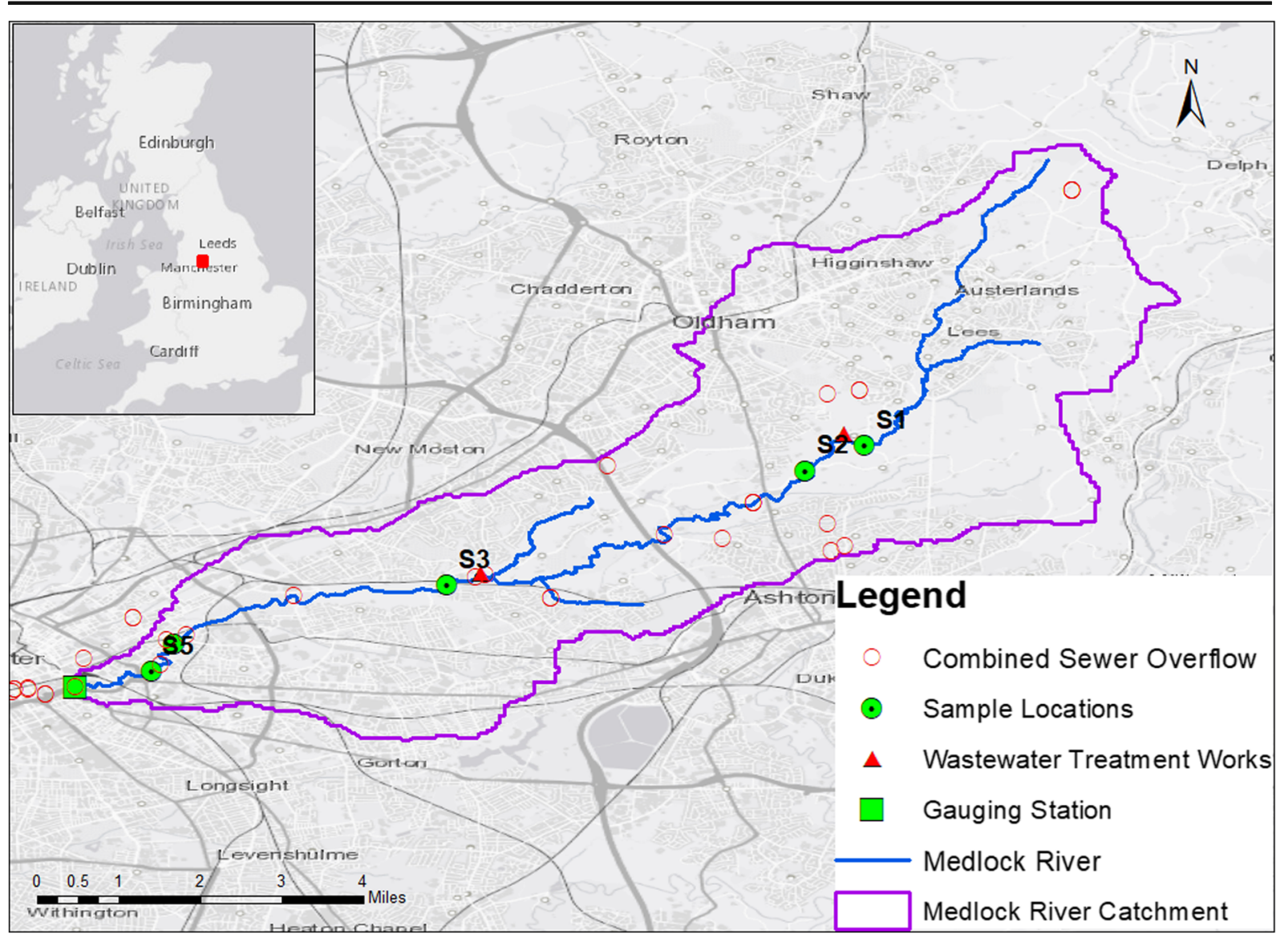

Fig. 1 River Medlock catchment area and the study sites, S1 to S5. The sites are located upstream and downstream of the main wastewater treatment works and combined sewer overflows. The

(National Grid Reference (NGR): SD 95308 05431). It passes through a steep-sided wooded region for 6.21 miles before entering a largely urbanised area of Manchester city centre (NGR: SJ 85781 97858).

Much of the catchment is heavily urbanised (53\%), but also consists of woodland and grassland comprising $43 \%$ of the catchment (CEH 2017). The surveyed reach of the river has a continuously operational wastewater treatment works (WwTW) at Failsworth (NGR: SJ 89674 99800), about 30 combined sewer overflows and numerous storm water overflows and surface water drains (EA, personal communication 2013).

Due to limited access to most parts of the river and given the small catchment area, a total of five sample sites (S1 to S5) were selected on the river upstream (sites $\mathrm{S} 1$ and S2) and downstream (sites S3 to S5) of the treatment works and combined sewer overflows (United Utilities, personal communication, 2013). river's gauge is located below site S5. Inset is the location of the river in Greater Manchester, UK

The catchment characteristics at each sub-section of the study sites including elevation, slope, dominant percentage land cover including grassland, built-up areas (comprising of urban and sub-urban cover) and woodlands are shown on Table 1. The Medlock catchment is dominated by grassland cover with the highest contribution at S1. S1 has an urban cover of $3.7 \%$ and the lowest catchment area when compared with other sample locations with higher urban covers. S1 also has the highest altitude and highest average slope. Appendix Table 10 shows equal distribution of the river substrate across sites with the dominant substrate recorded to be stones and sand.

Benthic macroinvertebrates

Monthly samples were obtained from the river between March 2013 and April 2014 for each of the five study 
Table 1 Catchment characteristics including the sub-catchment sampling sites S1-S5 and percentage contributions of the major land cover patterns at the study locations

\begin{tabular}{|c|c|c|c|c|c|c|c|c|}
\hline \multirow[t]{2}{*}{$\begin{array}{l}\text { Sub- } \\
\text { catchment }\end{array}$} & \multicolumn{4}{|c|}{ Catchment characteristics } & \multirow[t]{2}{*}{$\begin{array}{l}\text { Grassland } \\
(\%)\end{array}$} & \multirow[t]{2}{*}{$\begin{array}{l}\text { Woodland } \\
(\%)\end{array}$} & \multicolumn{2}{|c|}{$\begin{array}{l}\text { Built-up areas } \\
(\%)\end{array}$} \\
\hline & $\begin{array}{l}\text { Average slope } \\
(\%)\end{array}$ & $\begin{array}{l}\text { Sub-catchment area } \\
\left(\text { miles }^{2}\right)\end{array}$ & $\begin{array}{l}\text { Minimum elevation } \\
\text { (mMSL) }\end{array}$ & $\begin{array}{l}\text { Altitude } \\
(\mathrm{m})\end{array}$ & & & $\begin{array}{l}\text { Sub- } \\
\text { urban }\end{array}$ & Urban \\
\hline S1 & 10.72 & 5.27 & 182 & 140 & 47.6 & 14.2 & 21.1 & 3.7 \\
\hline S2 & 9.45 & 7.93 & 159 & 107 & 40.8 & 14.1 & 20.7 & 10.5 \\
\hline S3 & 7.56 & 16.98 & 114 & 78.9 & 38.5 & 14.4 & 22.4 & 10.5 \\
\hline S4 & 7.24 & 19.37 & 93 & 36.1 & 36.8 & 14.6 & 22.8 & 12.3 \\
\hline S5 & 7.21 & 19.63 & 90 & 33.6 & 36.8 & 14.3 & 22.9 & 12.3 \\
\hline
\end{tabular}

locations and at four seasons including winter (December to February), spring (March to May), summer (June to August) and autumn (September to November). In order to obtain an accurate representation of total biodiversity (Armitage et al. 2012) across space and time, 3min kick net sampling technique (Metzeling et al. 2003) was applied to collect benthic macroinvertebrates from the sites by using a 1-mm mesh net. An additional 1-min visual search was carried out to collect benthic invertebrates under stones that could have been missed through kick sampling (Murray-Bligh 2002). Replicates obtained at each site per sample period of 14 months were processed by using the qualitative standard method (Murray-Bligh 2002). Benthic macroinvertebrates were identified to family level in order to calculate the biotic indices including Biological Monitoring Working Party (BMWP) (Hawkes 1997) and Whalley, Hawkes, Paisley and Trigg (WHPT) (Clarke and Davy-Bowker 2014; Environment Agency 2015).

Physicochemical variables

The variables - temperature, $\mathrm{pH}$, dissolved oxygen (DO) and conductivity - were obtained at each site by using a pre-calibrated hand-held multiparameter water quality meter (YSi 556 Multi probe system YSI, Yellow Springs, OH, USA). Monthly spot samples were obtained at each site from March 2013 to April 2014 for the measurement of biochemical oxygen demand (BOD), phosphate- $\mathrm{P}\left(\mathrm{PO}_{4}-\mathrm{P}\right)$, nitrate-N $\left(\mathrm{NO}_{3}-\mathrm{N}\right)$, ammonia- $\mathrm{N}\left(\mathrm{NH}_{3}-\mathrm{N}\right)$ and suspended solid concentrations $(\mathrm{mg} / \mathrm{L})$.
For the measurement of nutrients, $300 \mathrm{ml}$ of water sample was filtered through a $0.45-\mu \mathrm{m}$ Millipore (Millipore-UK, Limited) hydrophilic, 47-mm cellulose acetate filter. The samples were processed within $24 \mathrm{~h}$ of collection and analysed using a SEAL Auto Analyzer 3 High Resolution instrument (SEAL Analytical Ltd., Southampton) based on a segmented flow analysis. For further information on the methods, see SEAL Analytical (2013). Throughout this study, concentrations of nutrients were presented as elemental concentrations, i.e. $\mathrm{mg} \mathrm{L}^{-1} \mathrm{P}$, not $\mathrm{PO}_{4}$ and $\mathrm{mg} \mathrm{L}^{-1} \mathrm{~N}$, not of $\mathrm{NO}_{3}$; ammonia as $\mathrm{mg} \mathrm{L}^{-1}$ of $\mathrm{N}$ not $\mathrm{NH}_{3}$. Detection limits for $\mathrm{PO}_{4}-\mathrm{P}$ measured as $\mathrm{P}$ was $0.004 \mathrm{mg} \mathrm{\textrm {L } ^ { - 1 }}$. Nitrate $\left(\mathrm{NO}_{3}-\mathrm{N}\right)$ measured as $\mathrm{N}$ following the DIN 38405 and ISO/DIS 13359 standard methods has a detection limit of $0.01 \mathrm{mg} \mathrm{L}^{-1}$. $\mathrm{NH}_{3}-\mathrm{N}$ concentration $\left(\mathrm{mg} \mathrm{L}^{-1}\right)$ was analysed by spectrophotometry using the Hanna low range reagent kit HI-93700-01 (Hanna Instruments Ltd., Leighton Buzzard, Bedfordshire). The limit of detection for $\mathrm{NH}_{3}-\mathrm{N}$ measured as $\mathrm{N}$ was $0.01 \mathrm{mg} \mathrm{L}^{-1}$. All samples were processed by using the standard methods of analysis (Environment Agency 2011).

River discharge The area ratio (AR) method (Archfield and Vogel 2010) was used to estimate river discharge at each sampling site using the following equation: $Y_{i a}=\left(A_{y} / A_{x}\right) X_{i a}$, where $Y_{i a}$ is the estimated discharge for month ${ }_{i}$ and year ${ }_{a}$ for site of interest; $A_{y}$ is the catchment area of site of interest; $A_{x}$ is the catchment area of gauging station; and $X_{i a}$ is the discharge for month ${ }_{i}$ and year ${ }_{a}$ for site of interest for gauging station. 
Data analysis

The degree of similarity/differences between the benthic macroinvertebrate communities in relation to study locations and time was visualised using the similarity percentages (SIMPER) analysis. By applying the Bray Curtis dissimilarity metric, the speciesabundance data were $\log (x+1)$ transformed prior to SIMPER analysis and cutoff for low contributions was at $90.00 \%$. All environmental variables including dissolved oxygen, temperature, conductivity, suspended solids, discharge, nutrients, river substrate, slope, altitude and sub-catchment areas were analysed using the principal component analysis (PCA) to characterize the physicochemical variation and benthic macroinvertebrates across the Medlock catchment. The first few PCs allow an accurate representation of the true relationship between the samples in the original high dimensional space as summarised by the percentage variation (Eigenvalues). The biological and environmental (BIOENV) analysis based on Spearman's correlation matrix was used to determine which variable(s) affected benthic invertebrate abundance and distribution. All data matrix were square root transformed and normalised on a distance matrix to allow comparisons on the scale with the benthic macroinvertebrates and physicochemical variables. The weighed Spearman rank correlation coefficient $(\rho)$ between the physicochemical variables and benthic invertebrate community similarity matrices formed the basis for this procedure. The physicochemical variable(s) with the largest $\rho$ was taken to identify the best match with the benthic macroinvertebrates. All multivariate analyses were performed using PRIMER 6 (Clarke and Gorley 2006). Repeated measures ANOVA was determined for the environmental variables in GraphPad Prism version 8.2.1.

Benthic macroinvertebrates samples were analysed and interpreted by using the pollution indices-the Biological Monitoring Working Party (BMWP) scores, Average Score Per Taxon (ASPT) (Hawkes 1997) and Whalley Hawkes Paisley and Trigg (Clarke and DavyBowker 2014; Environment Agency 2015). Families investigated were BMWP scoring taxa present in more than $1 \%$ of samples. The WHPT ASPT was determined by dividing the sum of each taxon abundance by the WHPT number of taxa and each taxa has an abundance weighting which is unavailable for BMWP individual taxa.
Table 2 Presence and absence of benthic macroinvertebrates along sites $\mathrm{S} 1$ to $\mathrm{S} 5$

\begin{tabular}{|c|c|c|c|c|c|}
\hline Groups & $\mathrm{S} 1$ & $\mathrm{~S} 2$ & $\mathrm{~S} 3$ & S4 & S5 \\
\hline \multicolumn{6}{|l|}{ Hirudinea (Annelida) } \\
\hline Erpobdellidae & 3 & 3 & 6 & 11 & 2 \\
\hline Glossiphonidae & & & 2 & 3 & \\
\hline \multicolumn{6}{|l|}{ Oligochaeta (Annelida) } \\
\hline Lumbricidae & 9 & 3 & 2 & 19 & 1 \\
\hline Lumbriculidae & 69 & 2 & 167 & 14 & 22 \\
\hline Tubificidae & 171 & 231 & 325 & 31 & 176 \\
\hline \multicolumn{6}{|l|}{ Crustacea (Arthropoda) } \\
\hline Gammaridae & 4 & 4 & 20 & 104 & 86 \\
\hline Asselidae & 4 & 4 & 26 & 3 & 1 \\
\hline \multicolumn{6}{|l|}{ Trichoptera (Arthropoda) } \\
\hline Rhyacophilidae & 4 & 7 & 4 & 5 & 5 \\
\hline Hydropsychidae & 5 & 8 & 7 & 10 & 7 \\
\hline Polycentropodidae & 4 & & & 2 & \\
\hline Limnephilidae & 1 & 26 & 3 & 14 & \\
\hline Psychomiyiidae & & 3 & & 1 & \\
\hline Hydroptilidae & & 2 & & & \\
\hline \multicolumn{6}{|l|}{ Coleoptera (Arthropoda) } \\
\hline Haliplidae & & & & 1 & \\
\hline Dytiscidae & 3 & 3 & & & \\
\hline Hydrophilidae & 1 & & & & \\
\hline \multicolumn{6}{|l|}{ Ephemeroptera (Arthropoda) } \\
\hline Baetidae & 111 & 239 & 217 & 200 & 71 \\
\hline Ephemerellidae & 18 & 19 & 3 & 1 & \\
\hline Heptageniidae & 125 & 51 & 22 & 14 & 10 \\
\hline Leptophlebiidae & 1 & & 4 & & \\
\hline Caeniidae & & 1 & & & \\
\hline \multicolumn{6}{|l|}{ Plecoptera (Arthropoda) } \\
\hline Perlodidae & 21 & 5 & & & \\
\hline Nemouridae & 11 & & & & \\
\hline Leuctridae & 14 & 13 & & & \\
\hline \multicolumn{6}{|l|}{ Diptera (Arthropoda) } \\
\hline Chironomidae & 155 & 173 & 77 & 120 & 107 \\
\hline Simulidae & 81 & 32 & 1 & 1 & 0 \\
\hline Tipulidae & 40 & 29 & 21 & 21 & 14 \\
\hline Paediciidae & 22 & 20 & & 6 & \\
\hline \multicolumn{6}{|l|}{ Mollusca } \\
\hline Sphaeridae & & & 1 & & \\
\hline Viviparidae & & & 2 & & \\
\hline Physidae & & & 2 & & 1 \\
\hline Lymnaeidae & & & 2 & & \\
\hline Total number of organisms & 877 & 878 & 914 & 581 & 503 \\
\hline Density (organisms/miles ${ }^{2}$ ) & 166 & 111 & 54 & 30 & 26 \\
\hline
\end{tabular}




\section{Results}

Benthic macroinvertebrates

\section{Spatial analysis}

The highest total number of organisms per site was recorded as follows: $\mathrm{S} 1(n=877), \mathrm{S} 2(n=878), \mathrm{S} 3$ $(n=914), \mathrm{S} 4(n=581)$ and S5 $(n=503)$ (Table 2$)$. Sampling each of the five sites resulted in a total of 3387 benthic macroinvertebrates representing six classes, 11 orders and 32 families. The identified families were distributed across three phyla Annelida (worms and leeches), Mollusca (Gastropods and bivalves) and Arthropoda (insects and crustaceans). Arthropods contributed 23 invertebrate families, which made up $72 \%$ of the total composition. The density of organisms was found to be highest at site $\mathrm{S} 1$ which corresponds to the area of highest river altitude and lowest urban cover and sub-catchment area.

Among the insects, the Ephemeroptera taxa dominated the invertebrate assemblage with $85 \%$ contribution, Plecoptera contributed 5\% and Trichoptera contributed $10 \%$ of organisms. Plecoptera was absent at the downstream stations S3 to S5 which could be linked to higher percentage cover, unsuitable substrate and contribution from contaminated urban runoff. Both sites S1 and S2 have lower \% urban cover and had organisms that could be found in clean rivers including some organisms of the order Ephemeroptera, Plecoptera and Trichoptera. The metric to determine the ratio of Gammaridae to Asellidae was shown to be $1: 1$ at sites $\mathrm{S} 1$ and $\mathrm{S} 2$, but higher at S4 with 35:1 and at S5, it was 84:1.

Although the total number of organisms counted at S3 was higher than S2, S3 contributed more by the presence of Oligochaetes and molluscs. These groups of organisms are BMWP low scoring, pollution tolerant organisms found in poor quality waters, and could be found in areas with higher percentage of urban cover and finer river substrates. However, Oligochaeta was found at all sites making up 52\% (comprising of $14 \%$ Lumbriculidae and Tubificidae, 38\%) of the total taxa followed by Baetidae which accounted for $19 \%$ and Chironomidae contributed $17 \%$ of the total composition. A significant difference $(p<0.05)$ was shown to exist between all sample sites (ANOVA). In particular, the lower $95 \%$ confidence interval showed a difference between sites $\mathrm{S} 1$ and $\mathrm{S} 5$.
Between sites, SIMPER results showed that the average dissimilarity between the upper and lower sites, i.e. for $\mathrm{S} 1$ and $\mathrm{S} 4$ was recorded at $70 \%$ and between $\mathrm{S} 1$ and $\mathrm{S} 5$ was shown to be $69 \%$. The differences between the upper and lower sites occurred due to higher contribution of Heptageniidae at S1 and Gammaridae at S4 and S5. Average dissimilarity between S1 and S3 was $67 \%$ also with Heptageniidae contributing at S1 but Tubificidae at S3. Apart from Heptageniidae which showed reduced numbers with increased catchment area and urban cover, other taxa groups including Baetidae, Tubificidae and Chironomidae showed increased abundance at the river (Table 2). The presence of Heptageniidae and Gammaridae organisms is associated with good and moderate river quality respectively while the presence of Tubificidae is indicative of diminished water quality. Within sites, the highest average similarity of organisms was found at site $4(45 \%)$ with the highest contribution by the crustacean Gammaridae followed by Baetidae. All other sites had similar contribution with
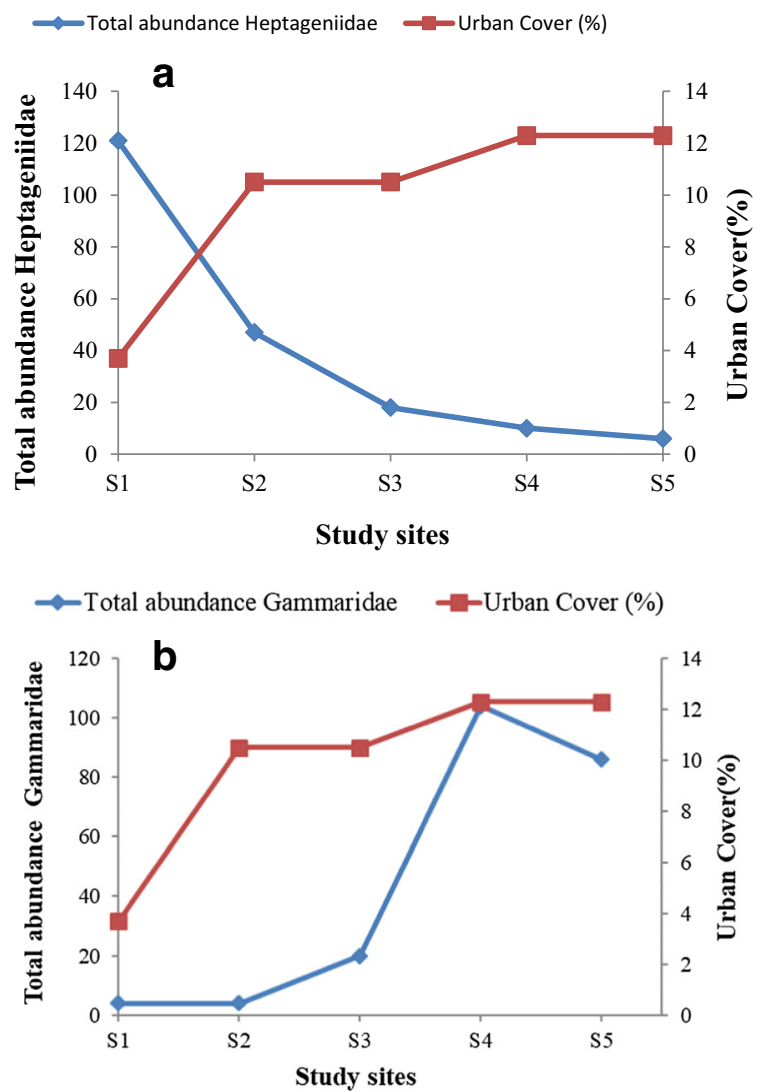

Fig. 2 Percentage cover across study sites and a total abundance of Heptageniidae and $\mathbf{b}$ total abundance of Gammaridae 
$40 \%$ similarity consisting of Baetidae and Chironomidae.

\section{Percentage urban cover and abundance of taxa}

The relationship between selected taxa including Heptageniidae and Gammaridae and percentage urban cover is displayed on Fig. 2. While urban cover increased for each site downstream of the river at sites S3 to S5, there was a reduction in the total abundance of Heptageniidae, Gammaridae abundance increased with increasing urban cover suggesting the tolerance of the crustacean to diverse conditions.

PC1 for benthic macroinvertebrates (Appendix Table 11) accounted for $12 \%$ of the overall variance and was weighted on Limnephilidae, Ephemerellidae, Caeniidae, Perlodidae, Nemouridae, Leuctridae, Psychomyiidae and Hydroptilidae with values more than 0.2 while PC 2 accounted for $11 \%$ of the variance weighted on caddisflies Hydropsychidae. Each of these organisms represents high BMWP scoring mayflies (Ephemerellidae and Caeniidae) and other pollution sensitive organisms including caddisflies (Limnephilidae, Hydroptilidae, Psychomyiidae and Hydropsychidae) and stoneflies (Perlodidae, Nemouridae and Leuctridae). These benthic macroinvertebrates including cased caddisflies (Limnephilidae, Hydroptilidae, Psychomyiidae and Hydropsychidae), stoneflies (Perlodidae, Nemouridae and Leuctridae) and mayflies (Ephemerellidae and Caeniidae) had the highest record at sites $\mathrm{S} 1$ and $\mathrm{S} 2$.

The scores for BMWP and WHPT were determined for each site and the results showed that the scores obtained for both indices were similar (Table 3). The WHPT calculator accounts for each family in the taxonomic orders of Molluscs, Hemiptera, Odonata, Diptera,
Trichoptera and Coleoptera. The presence and abundance per family in the listed groups imply that when more families are identified from among them, the higher the value allocated to them.

For other taxonomic groups such as Ephemeroptera, Crustacea and Hirudinea, only a few families were included in the WHPT calculator. For example, the invertebrate families included in the WHPT calculator are Ephemerellidae and Caenidae but not for Heptageniidae and Baetidae, Oligochaetes and Plecoptera.

For BMWP, most families present in the taxonomic order were counted as number of taxa. The interpretation of BMWP scores based on Hawkes (1997) showed that all sites except site S5 had good biological quality. For ASPT classification, sites S1 and S2 were 'good', S3 and S4 were 'moderate' and S5 was 'poor'. By applying the same interpretation to the WHPT indices, sites S1 to S4 would be classified as 'good' while site 5 would be considered 'moderate'. For WHPT ASPT, all the sites would be classified as 'very good'. This suggests that the WHPT index was more robust in interpretation better than BMWP. Statistically significant BMWP score showed degrading water quality from upstream, S1 to downstream sites S3 to S5 (ANOVA, $\left.F_{4,62}=3.4, p<0.05\right)$ and the difference was found between $\mathrm{S} 1$ and $\mathrm{S} 5$ (95\% CI of difference $=4.2$ to 38, $p=$ 0.0071-Tukey's test). Average Score Per Taxon (BMWP ASPT) also showed a statistically significant (ANOVA, $F_{4,62}=3.2, p<0.05$ ) difference between the sites and in particular between S1 and S3 (95\% CI of difference $=0.072$ to $3, p=0.0350$ - Tukey's test). Between sites, WHPT ASPT showed significant differences (ANOVA, $F_{4,62}=5.6, p<0.05$ ) between sites and Tukey's multiple comparison test shows the difference between S1 and S3 (95\% CI of difference $=0.47$ to

Table 3 Biotic indices-BMWP and WHPT scores and interpretation

\begin{tabular}{|c|c|c|c|c|c|c|c|c|}
\hline \multirow[b]{2}{*}{ Sites } & \multirow[b]{2}{*}{ BMWP NTAXA } & \multirow[b]{2}{*}{ BMWP score } & \multicolumn{3}{|l|}{ BMWP } & \multicolumn{3}{|l|}{ WHPT } \\
\hline & & & Category & ASPT & Category & WHPT score & WHPT ASPT & WHPT NTAXA \\
\hline $\mathrm{S} 1$ & 21 & 127 & Good & 6.05 & Good & 130.7 & 13.07 & 10 \\
\hline $\mathrm{S} 2$ & 19 & 114 & Good & 6 & Good & 124.3 & 10.34 & 12 \\
\hline $\mathrm{S} 3$ & 19 & 96 & Good & 5.05 & Moderate & 96.6 & 8.05 & 12 \\
\hline $\mathrm{S} 4$ & 17 & 86 & Good & 5.06 & Moderate & 93 & 8.45 & 11 \\
\hline S5 & 13 & 59 & Moderate & 4.53 & Poor & 49.7 & 9.94 & 5 \\
\hline
\end{tabular}


2.7, $p=0.0016) ; \mathrm{S} 1$ and $\mathrm{S} 4$ (95\% CI of difference $=$ 0.032 to $2.2, p=0.0407$ ); $\mathrm{S} 1$ and $\mathrm{S} 5$ (95\% CI of difference $=0.2$ to $2.5, p=0.0127)$ and between $\mathrm{S} 2$ and $\mathrm{S} 3$ (95\% CI of difference $=0.079$ to $2.3, p=0.029$ ).

\section{Temporal analysis}

The total number of organisms obtained during the seasons are recorded in decreasing order: spring $(1413)>$ winter $(1082)>$ summer $(519)>$ autumn (355). The highest and lowest records of organisms were found during spring and autumn respectively (see Appendix Table 12). For specific organisms, Fig. 3 shows organisms with $10 \%$ contribution with the highest contributions between seasons including Baetidae, Chironomidae, Gammaridae and Heptageniidae. The highest

\section{a. Baetidae}

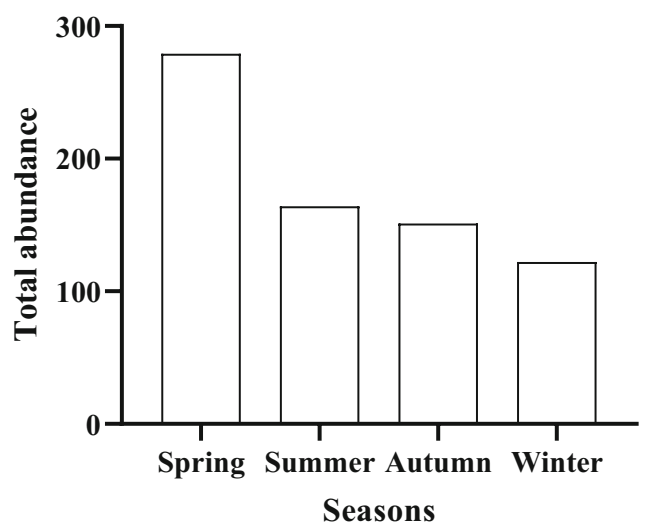

c. Heptageniidae

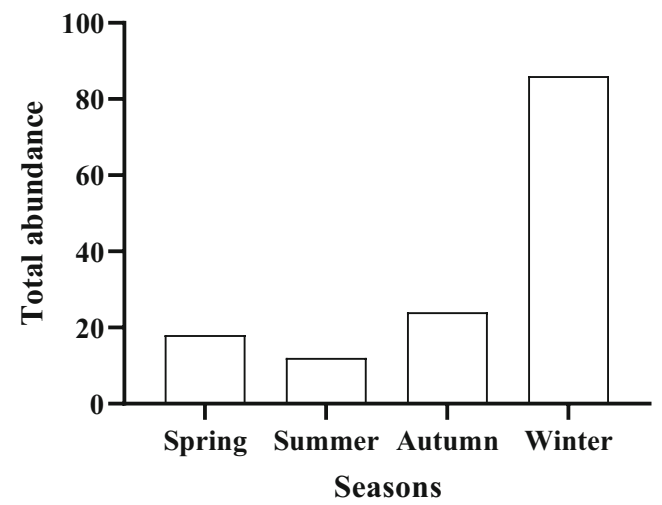

Fig. 3 Total abundance of organisms with $10 \%$ contribution between seasons. a Baetidae had the highest contribution during spring but declined gradually towards winter. b Chironomidae had a corresponding high contribution during spring, but had the average dissimilarity (65\%) of organisms was found between summer and autumn (Appendix Table 13) and this was distinct due to the presence/abundance of Chironomidae and Heptageniidae.

Within each season, Table 4 shows average similarity for benthic macroinvertebrates to be highest for spring (49\%) followed by autumn (37\%) and the lowest average similarity occurred during winter $(34 \%)$. For specific organisms, Baetidae had the highest percentage similarity contribution during autumn at $66 \%>$ summer $42 \%>$ spring $35 \%>$ winter $20 \%$. The next contributing taxa was Chironomidae which had the highest record during spring $26 \%>$ summer $19.9 \%>$ winter $16 \%>$ autumn $8.4 \%$. The ratio of Gammaridae to Asellidae was shown to be 3.3:1 during spring and winter, 18:1 during summer and 11:1 at autumn. These results imply that Gammaridae

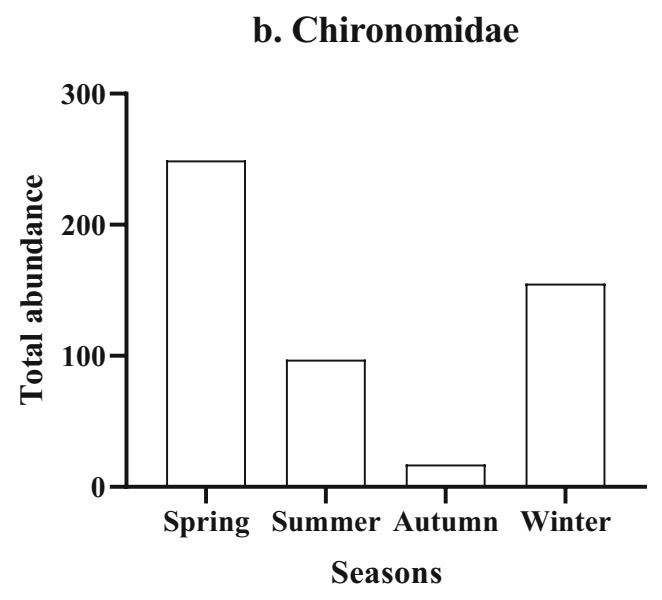

d. Gammaridae

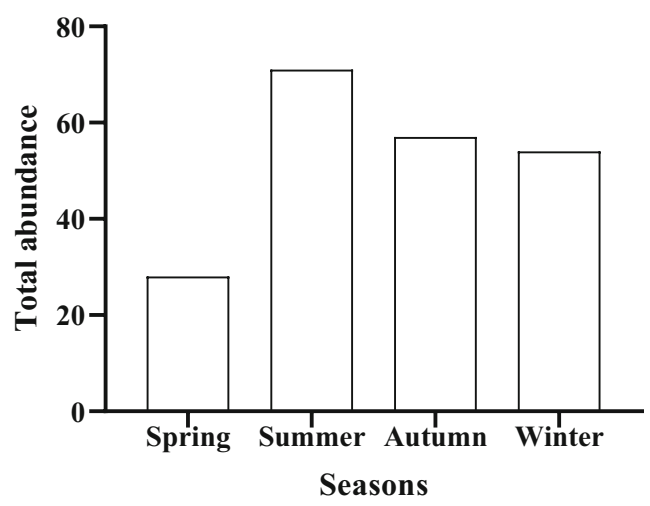

lowest record at autumn. $\mathbf{c}$ Heptageniidae had similar contribution during spring and winter while d Gammaridae had the highest contribution during the summer and the lowest at spring 
Table 4 Average abundance and similarity of organisms within each season from March 2013 to April 2014 for spring (MarchMay), summer (June-August), autumn (September to November)

\begin{tabular}{|c|c|c|c|}
\hline Spring average similarity, 49.17 & Contribution (\%) & Winter average similarity, 33.50 & Contribution (\%) \\
\hline Baetidae (E) & 34.8 & Baetidae (E) & 19.53 \\
\hline Chironomidae & 25.5 & Chironomidae & 15.96 \\
\hline Heptageniidae (E) & 10.5 & Tipulidae & 15.41 \\
\hline Gammaridae & 10.2 & Heptageniidae (E) & 11.63 \\
\hline Tubificidae & 3.93 & Hydropsychidae (T) & 7.63 \\
\hline Tipulidae & 3.35 & Tubificidae & 6.69 \\
\hline Lumbriculidae & 3.18 & Simulidae & 4.85 \\
\hline Autumn average similarity, 37.14 & Contribution $(\%)$ & Lumbriculidae & 3.9 \\
\hline Baetidae (E) & 66.1 & Erpobdellidae & 3.66 \\
\hline Chironomidae & 8.31 & Gammaridae & 3.42 \\
\hline Gammaridae & 7.91 & & \\
\hline Heptageniidae (E) & 6.68 & & \\
\hline Hydropsychidae (T) & 3.37 & & \\
\hline Summer average similarity, 36.50 & Contribution $(\%)$ & & \\
\hline Baetidae (E) & 42.2 & & \\
\hline Chironomidae & 19.9 & & \\
\hline Gammaridae & 10.5 & & \\
\hline Ephemerellidae (E) & 7.3 & & \\
\hline Tubificidae & 3.49 & & \\
\hline Heptageniidae (E) & 3.38 & & \\
\hline Lumbriculidae & 2.23 & & \\
\hline Rhyacophilidae (T) & 1.91 & & \\
\hline
\end{tabular}

Ephemeroptera (E); Plecoptera (P) and Trichoptera (T)

was abundant in the river compared to Asellidae at higher temperatures which favoured their growth.

BMWP scores (Table 5) showed that the river's status based on BMWP scores was good at all seasons while the ASPT showed the river's condition to be 'moderate'. and winter (December to February). Figures in italics highlight organisms with more than $10 \%$ contribution to the total organisms present at each season
When the same classification was applied to WHPT calculator, the river also achieved the status 'very good' biological quality as ASPT values were more than 8 . Between seasons, BMWP scores and ASPT showed no significant $(p>0.05)$ difference.

Table 5 Biotic indices-BMWP and WHPT scores, number of taxa (NTAXA) and average score per taxon (ASPT) determined for the sites on the basis of abundance

\begin{tabular}{|c|c|c|c|c|c|c|c|c|}
\hline \multirow[b]{2}{*}{ Season } & \multicolumn{5}{|l|}{ BMWP } & \multicolumn{3}{|l|}{ WHPT } \\
\hline & $\begin{array}{l}\text { BMWP } \\
\text { score }\end{array}$ & $\begin{array}{l}\text { Score } \\
\text { category }\end{array}$ & $\begin{array}{l}\text { BMWP } \\
\text { ASPT }\end{array}$ & $\begin{array}{l}\text { ASPT } \\
\text { category }\end{array}$ & $\begin{array}{l}\text { BMWP } \\
\text { NTAXA }\end{array}$ & $\begin{array}{l}\text { WHPT } \\
\text { score }\end{array}$ & $\begin{array}{l}\text { WHPT } \\
\text { NTAXA }\end{array}$ & $\begin{array}{l}\text { WHPT } \\
\text { ASPT }\end{array}$ \\
\hline Spring & 115 & Good & 5.23 & Moderate & 22 & 127 & 14 & 9.1 \\
\hline Summer & 118 & Good & 5.9 & Moderate & 20 & 124 & 12 & 10.33 \\
\hline Autumn & 103 & Good & 5.4 & Moderate & 19 & 108.5 & 12 & 9.042 \\
\hline Winter & 86 & Good & 5.37 & Moderate & 16 & 86.4 & 10 & 8.64 \\
\hline
\end{tabular}


Table 6 Mean \pm standard deviation of physicochemical variables at sites S1 to S5

\begin{tabular}{llllll}
\hline & $\mathrm{S} 1$ & $\mathrm{~S} 2$ & $\mathrm{~S} 3$ & $\mathrm{~S} 4$ & S5 \\
\hline $\mathrm{DO}(\%$ saturation) & $104.5 \pm 7.90$ & $100 \pm 8.62$ & $102.8 \pm 10.34$ & $100.8 \pm 9.85$ & $100.1 \pm 12.03$ \\
$\mathrm{pH}(\mathrm{pH}$ units) & $8.0 \pm 0.44$ & $7.8 \pm 0.29$ & $8.1 \pm 0.22$ & $8.1 \pm 0.26$ & $8.1 \pm 0.20$ \\
Temperature $\left({ }^{\circ} \mathrm{C}\right)$ & $9.7 \pm 3.32$ & $9.6 \pm 3.26$ & $10.7 \pm 4.06$ & $10.3 \pm 4.13$ & $10.3 \pm 4.29$ \\
Conductivity $\left(\mu \mathrm{S} \mathrm{cm}{ }^{-1}\right)$ & $484 \pm 129.92$ & $559.7 \pm 143.95$ & $650.3 \pm 149.80$ & $684.5 \pm 153.72$ & $693.7 \pm 154.61$ \\
Suspended solids $\left(\mathrm{mg} \mathrm{L}^{-1}\right)$ & $4.2 \pm 6.20$ & $6.0 \pm 5.77$ & $11.6 \pm 14.70$ & $15.0 \pm 26.68$ & $12.1 \pm 19.78$ \\
Discharge $\left(\mathrm{m}^{3} \mathrm{~s}^{-1}\right)$ & $0.15 \pm 0.12$ & $0.23 \pm 0.18$ & $0.43 \pm 0.34$ & $0.53 \pm 0.41$ & $0.53 \pm 0.41$ \\
$\mathrm{BOD}_{5}\left(\mathrm{mg} \mathrm{L}^{-1}\right)$ & $2.0 \pm 2.83$ & $2.3 \pm 2.62$ & $2.9 \pm 3.02$ & $3.3 \pm 3.20$ & $2.3 \pm 1.32$ \\
$\mathrm{NH}_{3}-\mathrm{N}\left(\mathrm{mg} \mathrm{L}^{-1}\right)$ & $0.4 \pm 0.55$ & $0.5 \pm 0.52$ & $0.6 \pm 0.58$ & $0.5 \pm 0.51$ & $0.5 \pm 0.58$ \\
$\mathrm{NO}_{3}$-N $\left(\mathrm{mg} \mathrm{L}^{-1}\right)$ & $0.9 \pm 1.09$ & $1.1 \pm 1.17$ & $4.0 \pm 3.04$ & $4.3 \pm 2.54$ & $4.1 \pm 2.27$ \\
$\mathrm{PO}_{4}-\mathrm{P}\left(\mathrm{mg} \mathrm{L}^{-1}\right)$ & $0.1 \pm 16$ & $0.1 \pm 0.25$ & $0.6 \pm 0.42$ & $0.5 \pm 0.34$ & $0.5 \pm 0.31$ \\
\hline
\end{tabular}

Environmental variables

\section{Spatial analysis and PCA of environmental variables}

The mean and standard deviation for the variables measured at the study river (see Table 6) indicated that all river sections sampled had high percentage oxygen

Table 7 Results of principal component analysis obtained for physicochemical and hydromorphological variables at the sampling locations

\begin{tabular}{|c|c|c|c|}
\hline Variable & $\mathrm{PC} 1(34 \%)$ & PC2 $(18 \%)$ & $\mathrm{PC} 3(12 \%)$ \\
\hline DO (\% saturation) & -0.072 & -0.06 & 0.231 \\
\hline pH (pH units) & 0.141 & -0.081 & -0.295 \\
\hline Temperature $\left({ }^{\circ} \mathrm{C}\right)$ & 0.022 & -0.001 & -0.444 \\
\hline Conductivity $\left(\mu \mathrm{S} \mathrm{cm}^{-1}\right)$ & 0.115 & 0.02 & 0.333 \\
\hline BOD & 0.138 & 0.025 & -0.024 \\
\hline $\mathrm{NH}_{3}-\mathrm{N}\left(\mathrm{mg} \mathrm{L}^{-1}\right)$ & 0.045 & 0.081 & 0.42 \\
\hline $\mathrm{NO}_{3}-\mathrm{N}\left(\mathrm{mg} \mathrm{L}^{-1}\right)$ & 0.304 & 0.008 & -0.259 \\
\hline $\mathrm{PO}_{4}-\mathrm{P}\left(\mathrm{mg} \mathrm{L}^{-1}\right)$ & 0.318 & -0.007 & -0.208 \\
\hline $\begin{array}{l}\text { Suspended solids } \\
\quad\left(\mathrm{mg} \mathrm{L}^{-1}\right)\end{array}$ & 0.148 & 0.18 & 0.185 \\
\hline Discharge $\left(\mathrm{m}^{3} \mathrm{~s}^{-1}\right)$ & 0.212 & 0.116 & 0.451 \\
\hline Catchment area $\left(\right.$ miles $\left.^{2}\right)$ & 0.372 & 0.071 & -0.001 \\
\hline Boulders $(\%)$ & -0.007 & 0.485 & -0.074 \\
\hline Stones $(\%)$ & -0.168 & 0.474 & -0.071 \\
\hline Pebbles (\%) & -0.356 & 0.124 & -0.055 \\
\hline Gravel (\%) & 0.136 & -0.098 & 0.077 \\
\hline Sand $(\%)$ & 0.15 & -0.445 & 0.05 \\
\hline Silt $(\%)$ & -0.144 & -0.487 & 0.059 \\
\hline Altitude (m) & -0.368 & -0.051 & 0.008 \\
\hline Slope (\%) & -0.364 & -0.061 & 0.002 \\
\hline
\end{tabular}

saturation, normal range $\mathrm{pH}$ and temperature conditions. Conductivity levels ranged from 484 to $693 \mu \mathrm{S} \mathrm{cm}^{-1}$ with the lowest value at site S1 and the highest at S5. The average concentration of BOD was less than $5 \mathrm{mg} \mathrm{L}^{-1}, \mathrm{NH}_{3}-\mathrm{N}<0.6 \mathrm{mg} \mathrm{L}^{-1}$ and $\mathrm{PO}_{4}-\mathrm{P}$ concentration which was more than $0.12 \mathrm{mg} / \mathrm{L}$ at sites $\mathrm{S} 3$ to $\mathrm{S} 5$. Classification of the river on the basis of WFD designation showed the river to be of 'poor' quality due to the concentration $(\mathrm{mg} / \mathrm{L})$ of $\mathrm{PO}_{4}-\mathrm{P}$.

Table 7 shows that PC1 accounted for $34 \%$ of the overall variance and was most heavily weighted on $\mathrm{PO}_{4}$ $\mathrm{P}, \mathrm{NO}_{3}-\mathrm{N}$ and catchment area. PC 2 accounted for $18 \%$ of the variance representing variations in river substrate specifically boulders and stones while PC3 was dominated by conductivity and discharge with a variance of $12 \%$. Discharge would influence the transport of substrate and nutrients faster across the river length to areas with reduced slope and altitude. With increased catchment area, water supplies could be abstracted for public use, urban runoff and effluent from housing and industrial development could increase contamination in wider catchment areas and more urbanised sites. These artificial influences operating within a larger catchment could alter natural runoff and therefore impact on flow and dilution of variables as demonstrated by sites S3 to S5.

\section{Temporal analysis of environmental variables}

Significant differences were found for $\mathrm{pH} F(1.436$, $5.746)=18.11, p=0.0043$; temperature $F(1.033$, $4.131)=220, p<0.0001$; conductivity $F(1.059$, $4.235)=35.76, p=0.0032$; BOD, $F(1.338,5.354)=$ $12.34, p=0.0127 ; \mathrm{NH}_{3}-\mathrm{N} F(2.026,8.103)=47.76$, 
Table 8 Weighted Spearman's rank correlation using between biotic and abiotic variables using the BIOENV procedure

\begin{tabular}{lll}
\hline $\begin{array}{l}\text { Number of } \\
\text { variables }\end{array}$ & $\begin{array}{l}\text { Weighted } \\
\text { Spearman's rank } \\
(\rho)\end{array}$ & Variables \\
\hline 5 & 0.274 & $\begin{array}{c}\text { Conductivity, discharge, } \\
\text { catchment area, altitude, slope } \\
\text { Conductivity, discharge, } \\
\text { catchment area, altitude } \\
\text { Conductivity, phosphate-P, } \\
\text { discharge, catchment area, } \\
\text { altitude } \\
\text { Conductivity, catchment area } \\
5\end{array}$ \\
0.273 & 0.272 & $\begin{array}{c}\text { Conductivity, nitrate-N, } \\
\text { discharge, catchment area, } \\
\text { altitude }\end{array}$ \\
\hline
\end{tabular}

$p<0.0001$ and TOM, $F(1.268,5.073)=17.08, p=$ 0.0075. During these seasons, the highest levels of $\mathrm{pH}$ and BOD were recorded during summer, $\mathrm{NH}_{3}-\mathrm{N}$ and TOM levels were highest during winter and conductivity level was highest during autumn. There were no significant $(p>0.05)$ differences found for $\mathrm{NO}_{3}-\mathrm{N}$, $\mathrm{PO}_{4}-\mathrm{P}$ and suspended solids.

Benthic macroinvertebrate assemblages

and environmental variables

Biological and environmental (BIOENV) test performed for environmental variables and benthic macroinvertebrate communities (Table 8 ) showed a weak correlation $\rho=0.274$ for five out of 20 variables. These five variables including conductivity, river discharge, catchment area, altitude and slope were shown to be the most important variables controlling the benthic macroinvertebrate abundance/richness. Although the correlation value was low (0.274), the iterations suggest that nutrient concentration $(\mathrm{mg} / \mathrm{l})$ especially $\mathrm{PO}_{4}-\mathrm{P}$ had no major influence on the abundance of benthic invertebrate community in this river. Instead, the relationship between the identified variables showed an increase in conductivity as discharge increased suggesting the impact of point source contribution; a strong correlation between discharge and catchment area suggests the impact of urban off and other point source contributions. However, as the slope decreased, the river discharge increased. Also, at high altitude, the percentage urban cover was lowest and the river concentrations were lowest which suggests an inverse relationship between altitude and catchment area.

Chronosequence of physicochemical variables and abundance of benthic macroinvertebrate assemblages

A time series of water chemistry, river discharge and benthic macroinvertebrates was analysed for sites S2 and S3 respectively (Fig. 4). The sites S2 and S3 are located upstream and downstream of the wastewater treatment works.

At site S2, the river discharge increased from $0.11 \mathrm{~m}^{3} / \mathrm{s}$ in 13 March 2019 (spring) until a peak of $0.72 \mathrm{~m}^{3} / \mathrm{s}$ in 11 December 2013 (winter) and gradually declined to $0.23 \mathrm{~m}^{3} / \mathrm{s}$ in 13 April 2014 (spring).

The highest concentration of suspended solids (14 mg/ 1) was recorded in 13 November 2019 (autumn) and for ammonia-N (0.9 mg/l) was recorded in 13 February 2014 (winter). All other levels of physicochemical variables recorded at S2 were low. The benthic macroinvertebrate which dominated the river was the mayfly, Baetidae, as the total number counts were distributed across the sample months. The highest count of Baetidae was recorded in spring (13 April 2013). This was followed by the worm, Tuficidae and in particular, 13 May 2013 (spring) showed an abundance of 150 total counts of Tubificidae at a discharge of $0.14 \mathrm{~m}^{3} / \mathrm{s}$. With increased discharge, the assemblage of Tubificidae reduced until 13 February 2014 (winter) where 50 counts were recorded at a discharge level of $0.37 \mathrm{~m}^{3} / \mathrm{s}$. Followed by Tubificidae is the taxa Chironomidae which had 89 and 55 counts in April and May respectively. Other taxa including Ephemerellidae were recorded in June (13 June 2013) and Heptageniidae, Paediciidae and Tipulidae were recorded from late winter to spring (February to April) of 2014 when the concentration of total organic matter was highest.

At S3, high concentration of suspended solid concentration $(39 \mathrm{mg} / \mathrm{l})$ was recorded in 13 August 2013 (summer) followed by a concentration of $28 \mathrm{mg} / \mathrm{l}$ which was 13 January 2014 (winter) the following year. The river discharge increased from $0.21 \mathrm{~m}^{3} / \mathrm{s}$ to a peak of $1.34 \mathrm{~m}^{3} / \mathrm{s}$ on 11 December 2013 (winter). The taxa Tubidicidae was abundant at S3 with peaks in 13 May 2013 (spring) and 13 January 2014 (winter). This was followed by Baetidae. The highest count for the worm Lumbricidae was recorded in 12 January 2014 (winter). 
Fig. 4 Benthic

macroinvertebrate abundance and physicochemical variables from a chronosequence of sites S2 and S3 which are upstream and downstream of a major WwTW. Data from the sample period was a full year from 13 March 2013 to 13 April 2014. Variables with the highest count were re-identified on the graphs
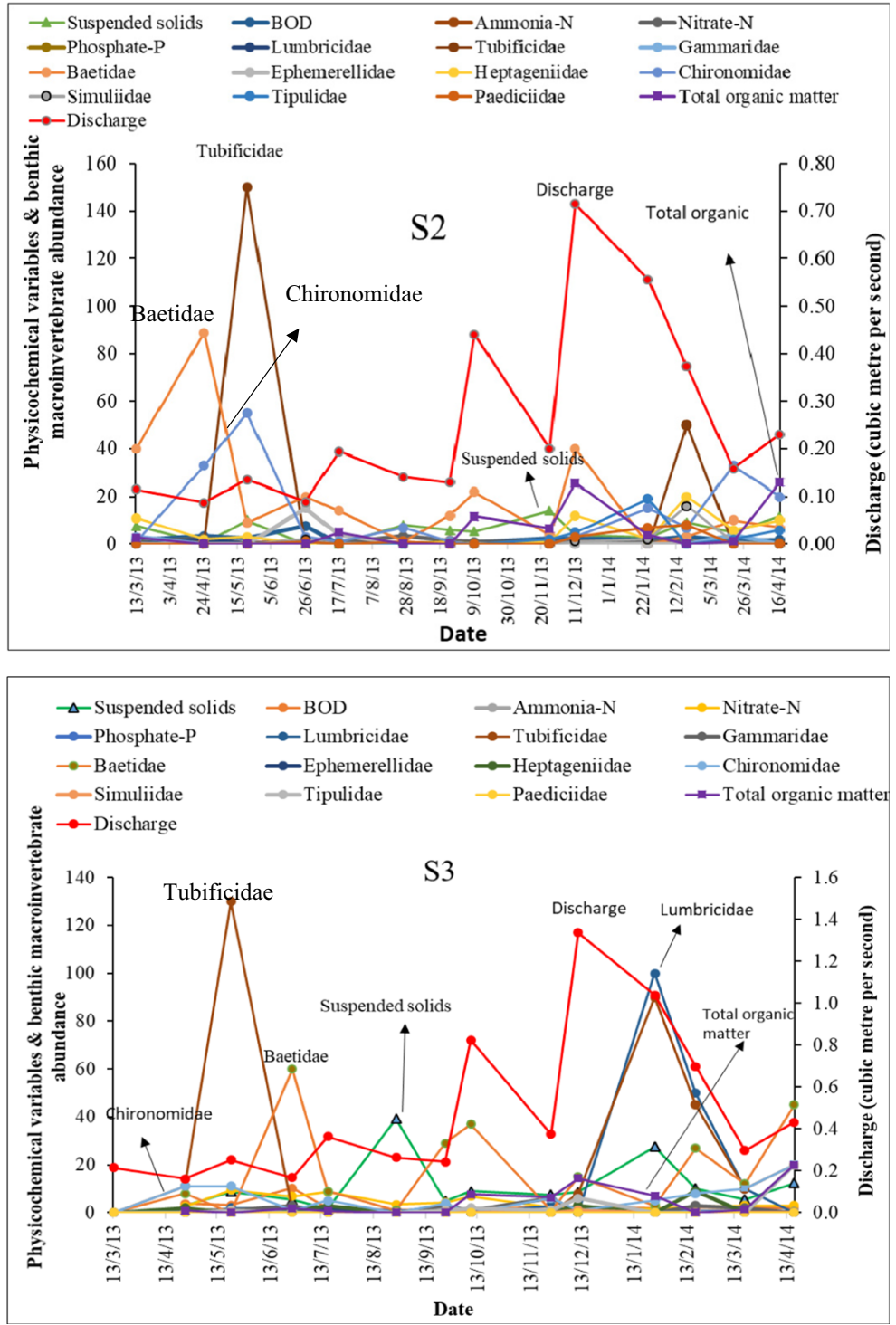

Nutrient concentration at S3 was higher than the records at site S2. The average phosphate-P concentration recorded at S3 was $0.58 \mathrm{mg} / \mathrm{l}$ compared to $0.08 \mathrm{mg} / \mathrm{l}$ recorded at $\mathrm{S} 2$; average nitrate- $\mathrm{N}$ concentration recorded at $\mathrm{S} 3$ was $4.33 \mathrm{mg} / \mathrm{l}$ and at $\mathrm{S} 2$, this was $1.03 \mathrm{mg} / \mathrm{l}$; average ammonia-N concentration recorded at $\mathrm{S} 3$ was $2.76 \mathrm{mg} / \mathrm{l}$ and at $\mathrm{S} 2$, this was $2.07 \mathrm{mg} / \mathrm{l}$; average concentration of suspended solids recorded at S3 was $11.03 \mathrm{mg} / \mathrm{l}$ and at $\mathrm{S} 2$, this was $5.98 \mathrm{mg} / \mathrm{l}$. Average river discharge recorded at $\mathrm{S} 3$ was $0.48 \mathrm{~m}^{3} / \mathrm{s}$ and at $\mathrm{S} 2$, this was $0.25 \mathrm{~m}^{3} / \mathrm{s}$.

The results from the two sites showed that Baetidae, Tubificidae and Chironomidae were abundant during spring when the river discharge was low but could be found in less abundance during winter when the river discharge was highest. The concentration of suspended solids was highest during summer when the river discharge was lowest. Highest average concentration of total organic matter $(11.96 \mathrm{mg} / \mathrm{l})$ was recorded at $\mathrm{S} 2$ between October (autumn) and January (winter) while $\mathrm{S} 3$ had a mean concentration in the same period of $8.83 \mathrm{mg} / \mathrm{l})$. Therefore, $\mathrm{S} 2$ will support more functional feeding groups such as shredders and grazers during autumn and winter seasons. These results correspond the findings of the 'Temporal analysis' and 'Temporal analysis of environmental variables' sections. 


\section{Discussion}

\section{Spatial variables}

Both benthic macroinvertebrates and physicochemical variables showed differences between the sites upstream and downstream of the wastewater treatment works. Abundant benthic macroinvertebrates and more environmentally sensitive organisms were found at the upper sites $\mathrm{S} 1$ and $\mathrm{S} 2$. These sites had the lowest concentration of physicochemical variables and high dissolved oxygen levels. On the basis of WFD classification, these sites would be considered to have achieved the 'good ecological status'. However, a river catchment is classified as a whole and on the basis of the weakest contributing variable (European 2000). Thus, a higher concentration of $\mathrm{PO}_{4}-\mathrm{P}$ concentration recorded at the lower sites S3 to S5 led to a 'poor' chemical status. High $\mathrm{PO}_{4}-\mathrm{P}$ concentration has been reported as a major challenge in this catchment (James et al. 2012) and the main pollution sources to the more urbanised sections of the river include the effluent received from the major treatment works, combined sewer overflows and diffuse pollution from leaked pipes and contaminated urban runoff. Similar patterns of downstream impacts of $\mathrm{PO}_{4}-\mathrm{P}$ concentration from treatment works have been found in other urban rivers as reported by Bowes et al. (2008), Jarvie et al. (2008); Morley and Karr (2002), Neal et al. (2005), Paul and Meyer (2001) and Walsh et al. (2001). Higher sub-catchment areas and urban covers were recorded at the locations downstream (sites S3 to S5) of the treatment works and these results suggest these locations will be impacted by other factors such as silted banks and modified river channels. These factors will impact on the river's ability to effectively perform its 'ecosystem service' including the maintenance of biodiversity (Brown 2007). Following this development, the river will not achieve 'good ecological status' as required by the EU WFD.

S1 and S2 had higher biotic scores and are classified as having 'good' quality status. Given the condition of S1 which was classified as 'good' for both physicochemical and ecological variables, this site could be used as a reference site to compare with other sections of the river. However, this may not be ideal because this section also receives effluent from CSOs and leachates from agricultural sites and therefore reveals the challenge of obtaining a control river site for studies in urban areas. The selection and application of a reference site in order to assess urban influence on parts of two Colorado river invertebrates have been studied (Voelz et al. 2005). Previous study of benthic invertebrates at River Medlock by Frost et al. (1976) showed that pollution tolerant Baetidae, Chironomidae and Oligochaeta had always been abundant especially at the lower reaches. Hence, after four decades and the operation of light industrial pollution from the city and post WFD implementation, these taxonomic groups still dominate the system, but the presence of moderately tolerant Gammaridae at the lower reaches indicates some improvement.

\section{Temporal variation}

The total taxon richness was higher in spring and winter than it was for summer and autumn. The percentage contribution for EPT was highest during spring with 94\% contribution from Ephemeroptera (with dominance by Baetidae), $0.9 \%$ Plecoptera and $4.8 \%$ for Trichoptera. The river's state of health was discriminated for study sites by the BMWP scores, higher discharge at the lower sites and the transport of nutrients and conductivity downstream of the river thereby suggesting the impact of other factors. The highest score for biotic indices was recorded during spring while the lowest score was recorded during winter. The reasons for the seasonal differences were attributed to the growing spring season which suggests abundant food for benthic macroinvertebrates. Although the highest dissimilarity of organisms was found between summer and winter (69\%), summer low flow leading to limited dilution, high nutrient influx could enhance abundant environmentally tolerant taxa and during winter increased flow will lead to increase urban runoff, high conductivity due to increased salt application to main roads and pathways. These conditions will favour organisms such Baetidae, Chironomidae and Oligochaeta which were in higher numbers. Other studies have found these groups to dominate the macroinvertebrate communities (Brittain et al. 2001; Guimaràes et al. 2009) especially in urban river systems (Minshall 1988; Townsend et al. 1997). During autumn, the highest level of conductivity recorded corresponds to the lowest total number of organisms recorded for the same period. This further suggests that high levels of ions do not favour the abundance of benthic macroinvertebrates. 
The ratio of Gammaridae to Asselidae was found to be highest during summer when the temperature was warm. Hynes (1955) showed that under summer conditions $\left(10-15^{\circ} \mathrm{C}\right)$, Gammaridae could mature between 3 and 4 months and during winter conditions $\left(5-10{ }^{\circ} \mathrm{C}\right)$, this would be about 7 months. During spring and winter, therefore, Gammaridae would be subject to heavy mortality or would be their resting stages.

Benthic macroinvertebrates and physicochemical variables

The relationship between benthic macroinvertebrates and physicochemical variables indicates that geomorphological variables co-vary with river discharge, river substrate and conductivity along the river sites which could influence their fauna assemblage. PCA for benthic macroinvertebrates (Appendix Table 11) showed that environmentally sensitive families structured the principal components. Therefore, the presence of these organisms suggests that the river was not influenced by environmental pollution. Echols et al. (2009) found mayflies were dominant where conductivity levels were lowest and show that high levels of conductivity could influence invertebrate numbers in a river. Some studies including Kefford (1998) and Roy et al. (2003) found a relationship between conductivity and benthic macroinvertebrates suggesting that a consistently elevated total dissolved ions may lead to biotic impairment of surface waters. Other sources of contamination including urban runoff, overflows and effluent from point sources, e.g. the wastewater treatment works, contribute to high concentrations of salts in the more urbanised sections of the river. Similar patterns have been found in urban rivers as reported by Morley and Karr (2002), Paul and Meyer (2001) and Walsh et al. (2001).

Chronosequence analysis ('Chronosequence of physicochemical variables and abundance of benthic 415 macroinvertebrate assemblages' section) supported the fact that the river was mostly influenced by the discharge contributions received from the WwTW above S3 and inflows from urban runoff at S3. Furthermore, increasing levels of discharge and nutrient concentration at S3 also supported the overflow contribution from combined sewers. These conditions influenced the abundance of environmentally tolerant taxa groups such as Oligochaeta, Baetidae and Chironomidae with less diversity of sensitive taxonomic groups, e.g. Heptageniidae and Ephemerellidae. While these results corroborate the findings of the 'Temporal analysis' section, a higher concentration of total organic matter recorded at site S2. These showed that S2 would favour functional feeders such as scrapers (e.g. Heptageniidae), shredders (e.g. Ephemerrelidae, Tipulidae) which are abundant in places with higher organic matter in particular leaf litter (Ramírez and Gutiérrez-Fonseca 2014) and indicates that S2 is more rural when compared with urban S3.

Altitude and slope correlated negatively on the PC 1 analysis and were found to influence the distribution of benthic macroinvertebrates. Environmentally sensitive EPT organisms were found at the locations of high altitude and slope in particular at sites S1 and S2. Although altitude and slope may co-vary in this study catchment, their differences may not be quite separable given the small catchment size. However, they may be influenced other variables such as increased discharge regimes which influence nutrient release through allochthonous energy influx (Bispo and Oliveira 2007; Vanessa et al. 2014) through the movement of substrate downstream of the river. These factors modify the composition and abundance of benthic macroinvertebrates (Miserendino 2001; Skoulikidis et al. 2009).

\section{Overall classification}

Both BMWP and WHPT indices showed the river to be 'very good' based on the WFD classification. With similarities in scores for BMWP and WHPT, both indices could provide a robust explanation by identifying selected organisms which could increase the river's taxa and therefore explain the state of the river at any given time. While BMWP index is simpler to apply in assessing pollution status (Roche et al. 2010) and the method of interpretation was found to be easier for the non-technical specialist, the WHPT index considers the abundance per taxa of certain groups of organisms in order to work out the scores.

Physicochemical variables such as high dissolved oxygen saturation, moderate concentration of $\mathrm{BOD}$

Table 9 WFD classifications from 2015 to 2021 cycle for the River Medlock

\begin{tabular}{llllll}
\hline $\begin{array}{l}\text { Classification } \\
\text { item }\end{array}$ & 2013 & 2014 & 2015 & 2016 & 2027 \\
\hline
\end{tabular}

Overall water Moderate Poor Moderate Moderate Good body

Ecological Moderate Poor Moderate Moderate Good

Chemical Good Good Good Good Good 
and $\mathrm{NH}_{3}-\mathrm{N}$ could increase the abundance of sensitive benthic macroinvertebrates and by proxy, the biotic indices across sites. The results obtained from this study show that sewage pollution is not a major challenge in this river apart from the higher concentration $(\mathrm{mg} / \mathrm{L})$ of $\mathrm{PO}_{4}-\mathrm{P}$. This result is in line with the report produced by the UK Environment Agency on the catchment classification (Table 9) under the WFD compliance scheme. It showed the river to be 'poor' in 2014 but has progressed to 'moderate' status in 2016 and all variables are predicted to be 'good' by 2027. The reasons for not achieving good status were attributed to intermittent sewage discharge (for benthic macroinvertebrates) and from urban development which caused the high phosphate concentration. (See https://environment.data.gov. uk/catchment-planning/WaterBody/GB112069061151. ) In order to achieve 'good ecological status', the environmental regulators will consider a need to balance the management priorities in relation to the cost of management and the extent of burdens on the river.

\section{Conclusion}

Urban rivers face challenges which influence the diversity, abundance and distribution of their organisms and some of these changes are irreversible. The metrics used to assess the river including total number of organisms, biotic indices (the BMWP, ASPT and WHPT), physicochemical variables and Gammaridae-Asellidae ratio have shown the river could be in 'good' condition especially at the downstream locations. The application of WHPT helped to improve our understanding of abundance weighting applied for benthic macroinvertebrates in river classification. With higher percentage urban cover recorded at the lower Appendix

Table 10 Mean river sediment substrate at sites S1 to S5

\begin{tabular}{llllllr}
\hline Substrate & $\begin{array}{l}\text { Boulders } \\
(\%)\end{array}$ & $\begin{array}{l}\text { Pebbles } \\
(\%)\end{array}$ & $\begin{array}{l}\text { Stones } \\
(\%)\end{array}$ & $\begin{array}{l}\text { Gravel } \\
(\%)\end{array}$ & $\begin{array}{l}\text { Sand } \\
(\%)\end{array}$ & $\begin{array}{l}\text { Silt } \\
(\%)\end{array}$ \\
\hline S1 & 5.50 & 6.50 & 36.50 & 4.50 & 30.00 & 15.00 \\
S2 & 10.00 & 4.50 & 39.09 & 6.50 & 28.64 & 12.27 \\
S3 & 4.00 & 1.00 & 27.00 & 22.50 & 32.00 & 12.22 \\
S4 & 13.50 & 2.50 & 43.00 & 6.00 & 27.50 & 7.50 \\
S5 & 5.63 & 1.43 & 17.50 & 3.75 & 41.88 & 15.63 \\
\hline
\end{tabular}

Table 11 PCA values obtained for benthic macroinvertebrate assemblages at the sampling locations

\begin{tabular}{|c|c|c|c|}
\hline Variable & PC1 $(11.9 \%)$ & PC2 (11.1\%) & PC3 $(8.7 \%)$ \\
\hline Erpobdellidae & -0.23 & 0 & -0.131 \\
\hline Glossiphonidae & -0.161 & 0.133 & -0.047 \\
\hline Lumbricidae & -0.171 & 0.169 & -0.149 \\
\hline Lumbriculidae & -0.108 & -0.049 & -0.022 \\
\hline Tubificidae & -0.153 & -0.298 & -0.159 \\
\hline Gammaridae & -0.164 & 0.122 & 0.136 \\
\hline Asselidae & -0.185 & 0.136 & -0.076 \\
\hline Rhyacophilidae & 0.036 & 0.134 & -0.236 \\
\hline Hydropsychidae & -0.047 & 0.218 & -0.188 \\
\hline Polycentropodidae & -0.106 & 0.185 & -0.202 \\
\hline Limnephilidae & 0.212 & 0.063 & -0.161 \\
\hline Haliplidae & -0.018 & 0.087 & 0 \\
\hline Dytiscidae & 0.145 & -0.197 & -0.144 \\
\hline Hydrophilidae & -0.017 & -0.197 & -0.125 \\
\hline Baetidae & 0.034 & 0.165 & -0.009 \\
\hline Ephemerellidae & 0.354 & -0.027 & -0.195 \\
\hline Heptageniidae & -0.058 & 0.177 & -0.31 \\
\hline Leptophlebiidae & -0.136 & -0.443 & -0.152 \\
\hline Caeniidae & 0.229 & -0.019 & 0.154 \\
\hline Perlodidae & 0.302 & -0.112 & -0.251 \\
\hline Nemouridae & 0.21 & -0.095 & -0.172 \\
\hline Leuctridae & 0.381 & -0.019 & -0.043 \\
\hline Psychomyiidae & 0.32 & 0.005 & -0.06 \\
\hline Hydroptilidae & 0.229 & -0.019 & 0.154 \\
\hline Chironomidae & -0.077 & -0.114 & -0.122 \\
\hline Simulidae & -0.005 & 0.119 & -0.327 \\
\hline Tipulidae & -0.155 & 0.139 & -0.307 \\
\hline Paediciidae & 0.073 & 0.064 & -0.405 \\
\hline Sphaeridae & -0.143 & -0.394 & -0.106 \\
\hline Viviparidae & -0.143 & -0.394 & -0.106 \\
\hline Physidae & -0.043 & -0.02 & 0.083 \\
\hline Lymnaeidae & 0.03 & -0.004 & 0.048 \\
\hline
\end{tabular}

sections, the river quality has been shown not be in a worst 
Table 12 The presence and absence of benthic macroinvertebrates across the four seasons: spring (March-May), summer (June to August), autumn (September to November) and winter (December to February)

\begin{tabular}{|c|c|c|c|c|}
\hline & Spring & Summer & Autumn & Winter \\
\hline \multicolumn{5}{|l|}{ Hirudinea (Annelida) } \\
\hline Erpobdellidae & 7 & & 6 & 12 \\
\hline Glossiphonidae & 1 & 1 & 1 & 2 \\
\hline \multicolumn{5}{|l|}{ Oligochaeta (Annelida) } \\
\hline Lumbricidae & 17 & 7 & & 10 \\
\hline Lumbriculidae & 28 & 9 & 38 & 199 \\
\hline Tubificidae & 565 & 7 & 3 & 209 \\
\hline \multicolumn{5}{|l|}{ Crustacea (Arthropoda) } \\
\hline Gammaridae & 36 & 71 & 57 & 54 \\
\hline Aselidae & 11 & 4 & 5 & 18 \\
\hline \multicolumn{5}{|l|}{ Trichoptera (Arthropoda) } \\
\hline Rhyacophilidae & 11 & 4 & 1 & 9 \\
\hline Hydropsychidae & 5 & 3 & 13 & 16 \\
\hline Polycentropodidae & 4 & 1 & & 1 \\
\hline Limnephilidae & 1 & 42 & & 1 \\
\hline Psychomiidae & & 2 & 1 & 1 \\
\hline Hydroptilidae & & & 2 & \\
\hline \multicolumn{5}{|l|}{ Coleoptera (Arthropoda) } \\
\hline Haliplidae & 1 & & & \\
\hline Dytiscidae & 2 & 3 & 1 & \\
\hline Hydrophilidae & 1 & & & \\
\hline \multicolumn{5}{|l|}{ Ephemeroptera (Arthropoda) } \\
\hline Baetidae & 326 & 164 & 151 & 122 \\
\hline Ephemerellidae & 0 & 39 & 1 & 1 \\
\hline Heptageniidae & 80 & 12 & 24 & 86 \\
\hline Leptophlebiidae & 5 & & & \\
\hline Caeniidae & & & 1 & \\
\hline \multicolumn{5}{|l|}{ Plecoptera (Arthropoda) } \\
\hline Perlodidae & 4 & 22 & & \\
\hline Nemouridae & & 11 & & \\
\hline Leuctridae & & 10 & 17 & \\
\hline \multicolumn{5}{|l|}{ Diptera (Arthropoda) } \\
\hline Chironomidae & 292 & 97 & 17 & 155 \\
\hline Simulidae & 9 & 3 & 1 & 82 \\
\hline Tipulidae & 16 & 1 & 11 & 67 \\
\hline Paediciidae & 5 & 4 & 2 & 37 \\
\hline \multicolumn{5}{|l|}{ Mollusca } \\
\hline Sphaeridae & 1 & & & \\
\hline Viviparidae & 2 & & & \\
\hline Physidae & 1 & & 2 & \\
\hline Lymnaeidae & & 2 & & \\
\hline Total number of organisms & 1431 & 519 & 355 & 1082 \\
\hline
\end{tabular}


Table 13 Average dissimilarities (SIMPER) between seasons spring (March to May), summer (June-August), autumn (September to November) and winter (December to January) based on average abundance and percentage contribution of benthic macroinvertebrate during study period. Figures in italics indicate organisms with $10 \%$ contribution to the total counts

\begin{tabular}{|c|c|c|c|}
\hline Summer and autumn average dissimilarity $=64.77$ & Contribution $(\%)$ & Spring and winter average dissimilarity $=60.75$ & Contribution (\%) \\
\hline Chironomidae & 10.58 & Baetidae & 9.67 \\
\hline Gammaridae & 9.72 & Chironomidae & 9.3 \\
\hline Heptageniidae & 7.28 & Gammaridae & 8.54 \\
\hline Ephemerellidae & 6.76 & Heptageniidae & 8.49 \\
\hline Baetidae & 6.71 & Tubificidae & 8.4 \\
\hline Tubificidae & 6.6 & Tipulidae & 7.98 \\
\hline Lumbriculidae & 5.44 & Lumbriculidae & 7.4 \\
\hline Leuctridae & 4.65 & Simulidae & 6.07 \\
\hline Hydropsychidae & 4.39 & Hydropsychidae & 5.41 \\
\hline Asselidae & 4.05 & Asselidae & 5.03 \\
\hline Lumbricidae & 3.74 & Paediciidae & 4.63 \\
\hline Tipulidae & 3.65 & Lumbricidae & 4.48 \\
\hline Erpobdellidae & 3.34 & Erpobdellidae & 4.45 \\
\hline Limnephilidae & 3.02 & Rhyacophilidae & 3.52 \\
\hline Paediciidae & 3 & & \\
\hline Rhyacophilidae & 2.85 & & \\
\hline Dytiscidae & 2.4 & & \\
\hline Perlodidae & 2.08 & & \\
\hline Spring and summer average dissimilarity $=59.57$ & Contribution $(\%)$ & Spring and autumn average dissimilarity $=58.59$ & Contribution (\%) \\
\hline Chironomidae & 8.98 & Chironomidae & 13.11 \\
\hline Heptageniidae & 8.61 & Heptageniidae & 10.38 \\
\hline Tubificidae & 8.6 & Gammaridae & 9.79 \\
\hline Gammaridae & 8.4 & Tubificidae & 7.74 \\
\hline Lumbriculidae & 5.99 & Lumbriculidae & 7.34 \\
\hline Baetidae & 5.87 & Tipulidae & 6.79 \\
\hline Ephemerellidae & 5.79 & Baetidae & 6.36 \\
\hline Tipulidae & 5.34 & Asselidae & 6.23 \\
\hline Lumbricidae & 5.08 & Hydropsychidae & 4.56 \\
\hline Asselidae & 4.68 & Lumbricidae & 4.3 \\
\hline Rhyacophilidae & 3.43 & Erpobdellidae & 4.24 \\
\hline Simulidae & 3.41 & Paediciidae & 4.03 \\
\hline Erpobdellidae & 3.29 & Simulidae & 2.85 \\
\hline Paediciidae & 3.07 & Rhyacophilidae & 2.18 \\
\hline Leuctridae & 3 & Leuctridae & 1.86 \\
\hline Perlodidae & 2.72 & & \\
\hline Limnephilidae & 2.7 & & \\
\hline Hydropsychidae & 2.58 & & \\
\hline
\end{tabular}


condition but demonstrated that urban influence could impact on the river's biodiversity. Modifications of urban rivers are permanent; their management will therefore require treatment on a case by case basis in order to effectively manage the urban river as a sustainable resource for all. An integrated catchment approach could be adopted which includes river basin development groups, catchment caretakers, environmental regulators, water companies and members of the public to protect and sustain our rivers and other waterbodies. While some parts of the urban river will require maintenance, others will need to be restored and prevention of more urbanised areas will be a major challenge as human population and development increases.

Acknowledgements The author wishes to thank Dr. Kofi Owusu, University of Manchester, UK, for producing the map, Fig. 1.

\section{Compliance with ethical standards}

Conflict of interest The author declares that she has no conflict of interest.

Open Access This article is licensed under a Creative Commons Attribution 4.0 International License, which permits use, sharing, adaptation, distribution and reproduction in any medium or format, as long as you give appropriate credit to the original author(s) and the source, provide a link to the Creative Commons licence, and indicate if changes were made. The images or other third party material in this article are included in the article's Creative Commons licence, unless indicated otherwise in a credit line to the material. If material is not included in the article's Creative Commons licence and your intended use is not permitted by statutory regulation or exceeds the permitted use, you will need to obtain permission directly from the copyright holder. To view a copy of this licence, visit http://creativecommons.org/licenses/by/4.0/.

\section{References}

Archfield, S. A., \& Vogel, R. M. (2010). Map correlation method: selection of a reference streamgage to estimate daily streamflow at ungaged catchments. Water Resources Research, 46(10), 1-15. https://doi.org/10.1029/2009 WR008481.

Armitage, P. D., Moss, D., Wright, J. F., \& Furse, M. T. (1983). The performance of a new biological water quality score system based on macroinvertebrates over a range of unpolluted running water sites. Water Research, 17(3), 333-347.

Armitage, P. D., Hawczak, A., \& Blackburn, J. H. (2012). Tyre track pools and puddles - anthropogenic contributors to aquatic biodiversity. Limnologica, 42(4), 254-263. https://doi.org/10.1016/j.limno.2012.07.002.

Bispo, P. C., \& Oliveira, L. G. (2007). Diversity and structure of Ephemeroptera, Plecoptera and Trichoptera (Insecta) assemblages from riffles in mountain streams of Central Brazil. Revista Brasileira de Zoologia, 24(2), 283-293. https://doi. org/10.1590/S0101-81752007000200004.

Booth, D. B., Karr, J. R., Schauman, S., Konrad, C. P., Morley, S. A., Larson, M. G., \& Burges, S. J. (2005). Reviving urban streams: land use, hydrology. Journal of the American Water Resources Association, 98195(5), 1351-1364. https://doi. org/10.1111/j.1752-1688.2004.tb01591.x.

Bowes, M. J., Smith, J. T., Jarvie, H. P., \& Neal, C. (2008). Modelling of phosphorus inputs to rivers from diffuse and point sources. Science of the Total Environment, 395, 125138. https://doi.org/10.1016/j.scitotenv.2008.01.054.

Brittain, J. E., Saltveit, S. J., Castella, E., Bogen, J., Bønsnes, T. E., Blakar, I., et al. (2001). The macroinvertebrate communities of two contrasting Norwegian glacial rivers in relation to environmental variables. Freshwater Biology, 46(12), 1723-1736. https://doi.org/10.1046/j.13652427.2001.00854.x.

Brown, B. L. (2007). Habitat heterogeneity and disturbance influence patterns of community temporal variability in a small temperate stream. Hydrobiologia, 586(1), 93-106. https://doi.org/10.1007/s10750-006-0531-3.

Chadwick, M. A., Dobberfuhl, D. R., Benke, A. C., Huryn, A. D., Suberkropp, K., \& Thiele, J. E. (2010). Urbanization affects stream ecosystem function by altering hydrology, chemistry, and biotic richness. Ecological Applications, 16(5), 17961807. https://doi.org/10.1890/1051-0761(2006)016[1796 :UASEFB]2.0.CO;2.

Chin, A. (2006). Urban transformation of river landscapes in a global context. Geomorphology, 79(3-4), 460-487. https://doi.org/10.1016/j.geomorph.2006.06.033.

Chin, A., \& Gregory, K. J. (2005). Managing urban river channel adjustments. Geomorphology, 69(1-4), 28-45. https://doi. org/10.1016/j.geomorph.2004.10.009.

Clarke, R., \& Davy-Bowker, J. (2014). River invertebrate classification tool science development project: modifications for WHPT and other abundance-weighted indices a report to the Scottish Environment Protection Agency, Freshwater Biology Association. S/0008/R pp92 Freshwater Biology Association, United Kingdom.

Clarke, K.R., Gorley, R.N. (2006) PRIMER v6: User Manual/ Tutorial. PRIMER-E: Plymouth, UK

Council of the European Union. (2000). Water Framework Directive 2000/60/EC -Official. Journal of the European Communities 72.

Czerniawska-Kusza, I. (2004). Use of artificial substrates for sampling benthic macroinvertebrates in the assessment of water quality of large lowland rivers. Polish Journal of Environmental Studies, 13(5), 579-584.

Echols, B. S., Currie, R. J., \& Cherry, D. S. (2009). Influence of conductivity dissipation on benthic macroinvertebrates in the North Fork Holston River, Virginia downstream of a point source brine discharge during severe low-flow conditions. Human and Ecological Risk Assessment, 15(1), 170-184. https://doi.org/10.1080/10807030802615907.

Elosegi, A., Gessner, M. O., \& Young, R. G. (2017). River doctors: learning from medicine to improve ecosystem 
management. Science of the Total Environment, 595, 294 302. https://doi.org/10.1016/j.scitotenv.2017.03.188.

Environment Agency. (2009). Water for life and livelihoods: River Basin Management Plan North West River Basin District. Bristol, UK.

Environment Agency. (2015). Whalley Hawkes Paisley Trigg (WHPT) index of river invertebrate quality. A brief description of WHPT for river invertebrate assessment in the UK under the water framework directive.

Environment Agency Standing Committee of Analysts (2011). Index of methods for the examination of waters and associated materials 1976-2011. Environment Agency National Laboratory Service. https://www.environment-agency.gov. $\mathrm{uk} / \mathrm{nls}$.

Frost, S., Chiu, M. T. L., Pugh Thomas, M., \& Pugh-Thomas, M. (1976). Seasonal changes of invertebrate populations in the polluted River Medlock. Environmental Pollution (1970), 11(3), 223-242. https://doi.org/10.1016/0013-9327(76 )90087-2.

Guimaràes, R. M., Facure, K. G., Pavanin, L. a., \& Jacobucci, G. B. (2009). Water quality characterization of urban streams using benthic macroinvertebrate community metrics. Acta Limnologica Brasiliensia, 21(2), 217-226.

Hawkes, H. (1997). Origin and development of the biological monitoring working party score system. Water Research, 32(3), 964-968. https://doi.org/10.1016/S0043-1354(97 )00275-3.

Hellawell, J. M. (1986). In K. Mellanby (Ed.), Biological indicators of freshwater pollution and environmental management (Pollution Monitoring Series). London: Elsevier Applied Science Publishers.

Hynes, H. B. N. (1955). The Reproductive Cycle of Some British Freshwater Gammaridae. British Ecological Society, 24, 352-387.

James, P., Atkinson, S., Barlow, D., Bates, A., Comyn, F., Duddy, M., ... Causer, K. (2012). The Irwell catchment pilot: the rivers return. Warrington, UK: The Environment Agency.

Jarvie, H. P., Haygarth, P. M., Neal, C., Butler, P., Smith, B., Naden, P. S., ... Palmer-Felgate, E. J. (2008). Stream water chemistry and quality along an upland-lowland rural land-use continuum, south west England. Journal of Hydrology, 350, 215-231. https://doi.org/10.1016/j.jhydrol.2007.10.040.

Kefford, B. J. (1998). The relationship between electrical conductivity and selected macroinvertebrate communities in four river systems of south-west Victoria, Australia. International Journal of Salt Lake Research, 7(2), 153-170. https://doi.org/10.1007/BF02441884.

Lock, K., Asenova, M., \& Goethals, P. L. M. (2011). Benthic macroinvertebrates as indicators of the water quality in Bulgaria: a case-study in the Iskar river basin. Limnologica, 41(4), 334-338. https://doi.org/10.1016/j. limno.2011.03.002.

Metzeling, L., Chessman, B., Hardwick, R., \& Wong, V. (2003). Rapid assessments of rivers using macroinvertebrates: the role experience, and comparison with quantitative methods. Hydrobiologia, 510, 39-52. https://doi.org/10.1023 /B:HYDR.0000008500.34301.a0.

Meyer, J. L., Paul, M. J., \& Taulbee, W. K. (2005). Stream ecosystem function in urbanizing landscapes. Journal of the North American Benthological Society, 24(3), 602-612. https://doi.org/10.1899/04-021.1.
Minshall, G. W. (1988). Stream ecosystem theory: a global perspective. Journal of the North American Benthological Society, 7(4), 263-288. https://doi.org/10.2307/1467294.

Miserendino, M. L. (2001). Macroinvertebrate assemblages in Andean Patagonian rivers and streams: environmental relationships. Hydrobiologia, 444, 147-158. https://doi. org/10.1023/A:1017519216789.

Morley, S. A., \& Karr, J. R. (2002). Assessing and restoring the health of urban streams in the Puget Sound Basin. Conservation Biology, 16(6), 1498-1509. https://doi. org/10.1046/j.1523-1739.2002.01067.x.

Murray-Bligh, J. (2002). UK invertebrate sampling and analysis procedure for STAR project. In EU STAR Project. Retrieved from http://www.eu-star.at/pdf/RivpacsMacro invertebrateSamplingProtocol.pdf. Accessed 4 June 2019.

National Rivers Flow Archive, Centre for Ecology and Hydrology (2017) https://nrfa.ceh.ac.uk/data/station/spatial/69020. Accessed 4 June 2019

Neal, C., Jarvie, H. P., Neal, M., Love, A. J., Hill, L., \& Wickham, H. (2005). Water quality of treated sewage effluent in a rural area of the upper Thames Basin, southern England, and the impacts of such effluents on riverine phosphorus concentrations. Journal of Hydrology, 304, 103-117. https://doi. org/10.1016/j.jhydrol.2004.07.025.

Paul, M. J., \& Meyer, J. L. (2001). Streams in the urban landscape. Annual Review of Ecology and Systematics, 32, 333-365. https://doi.org/10.1146/annurev.ecolsys.32.081501.114040.

Purcell, A. H., Friedrich, C., Resh, V. H., Creek, B., \& Cerrito, E. (2002). An assessment of a small urban stream restoration project in Northern California. 10(4), 685-694.

Ramírez, A., \& Gutiérrez-Fonseca, P. E. (2014). Functional feeding groups of aquatic insect families in Latin America: a critical analysis and review of existing literature. Revista de Biologia Tropical, 62(April), 155-167. https://doi. org/10.15517/rbt.v62i0.15785.

Roche, K. F., Queiroz, E. P., Righi, K. O., \& de Souza, G. M. (2010). Use of the BMWP and ASPT indexes for monitoring environmental quality in a neotropical stream. Acta Limnologica Brasiliensia, 22(01), 105-108. https://doi. org/10.4322/actalb.02201010.

Roy, A. H., Rosemond, A. D., Paul, M. J., Leigh, D. S., \& Wallace, J. B. (2003). Stream macroinvertebrate response to catchment urbanization (Georgia, U.S.A.). Freshwater Biology, 48(2), 329-346.

Skoulikidis, N. T., Karaouzas, I., \& Gritzalis, K. C. (2009). Identifying key environmental variables structuring benthic fauna for establishing a biotic typology for Greek running waters. Limnologica, 39(1), 56-66. https://doi.org/10.1016/j. limno.2008.01.002.

Townsend, C. R., Dolédec, S., \& Scarsbrook, M. R. (1997). Species traits in relation to temporal and spatial heterogeneity in streams: a test of habitat templet theory. Freshwater Biology, 37(2), 367-387. https://doi.org/10.1046/j.13652427.1997.00166.x.

Vanessa, A., Salvarrey, B., Kotzian, C. B., \& Spies, M. R. (2014). The influence of natural and anthropogenic environmental variables on the structure and spatial distribution along longitudinal gradient of macroinvertebrate communities in southern Brazilian streams. Journal of Insect Science, 14, $1-23$. 
Voelz, J. N., Zuellig, E. R., Shieh, S., \& Ward, J. V. (2005). Macroinvertebrates in two Colorado Plains Rivers. Environmental Monitoring and Assessment, 101, 175-202.

Walsh, C. J., Sharpe, A. K., \& Breen, P. F. (2001). Effects of urbanization on streams of the Melbourne Region, Victoria, Australia. I. Benthic macroinvertebrate communities. Freshwater Biology, 46, 535-551.

Walsh, C. J., Roy, A. H., Feminella, J. W., Cottingham, P. D., Groffman, P. M., Morgan, R. P., ... Ii, R. P. M. A. P. M. O. (2005). The urban stream syndrome: current knowledge and the search for a cure. Journal of North American Bethological Society, 24(3), 706-723. https://doi. org/10.1899/04-028.1.
Walsh, C. J., Fletcher, T. D., \& Burns, M. J. (2012). Urban stormwater runoff: a new class of environmental flow problem. PLoS One, 7(9). https://doi.org/10.1371/journal. pone. 0045814 .

WFD-UK Technical Advisory Group (UKTAG). (2014). River assessment method: benthic invertebrate fauna. United Kingdom.

Publisher's note Springer Nature remains neutral with regard to jurisdictional claims in published maps and institutional affiliations. 